\section{Commentary: The best of both worlds? Conversion of a neonatal modified Starnes procedure to biventricular circulation}

\author{
Ryan R. Davies, MD
}

The Starnes procedure has enabled the salvage of neonates with severe Ebstein anomaly, even those presenting in cardiogenic shock. ${ }^{1}$ However, it may carry a significant long-term downside by committing a patient to a longterm single-ventricle circulation due to an inability to tolerate the neonatal period of high pulmonary vascular resistance. Although outcomes with Fontan palliation in these patients, especially those with a modified Starnes procedure (fenestrated right ventricular exclusion) are good, there continues to be late mortality that may, in part, be attributable to the myriad negative consequences of the total cavopulmonary connection. ${ }^{2}$ The opportunity to use the Starnes procedure to palliate a neonate through the highrisk period while preserving subsequent conversion to a 2 -ventricle (or $1 \frac{1}{2}$-ventricle) circulation has the potential to improve long-term outcomes in these patients.

In the current issue of JTCVS Techniques, da Silva and colleagues $^{3}$ describe just such a pathway in 2 patients. There has been increasing interest in using the cone procedure for primary repair of the tricuspid valve in neonates. ${ }^{4-6}$ However, some patients may present in extremis and are unlikely to tolerate the longer procedure aimed at repairing the valve in the early neonatal period. In such patients, use of the Starnes procedure may be required to improve left ventricular function and systemic cardiac output while maintaining systemic oxygenation levels.

\footnotetext{
From the Department of Cardiovascular and Thoracic Surgery, UT Southwestern Medical Center and Children's Health, Dallas, Tex.

Disclosures: The author reported no conflicts of interest

The Journal policy requires editors and reviewers to disclose conflicts of interest and to decline handling or reviewing manuscripts for which they may have a conflict of interest. The editors and reviewers of this article have no conflicts of interest.

Received for publication May 15, 2020; revisions received May 15, 2020; accepted for publication May 21, 2020; available ahead of print June 1, 2020.

Address for reprints: Ryan R. Davies, MD, 1935 Medical District Dr, MC B3.410, Dallas, TX 75235 (E-mail: ryan.davies@utsouthwestern.edu).

JTCVS Techniques 2020;3:286-7

2666-2507

Copyright (C) 2020 The Authors. Published by Elsevier Inc. on behalf of The American Association for Thoracic Surgery. This is an open access article under the CC BY-NCND license (http://creativecommons.org/licenses/by-nc-nd/4.0/).

https://doi.org/10.1016/j.xjtc.2020.05.025
}

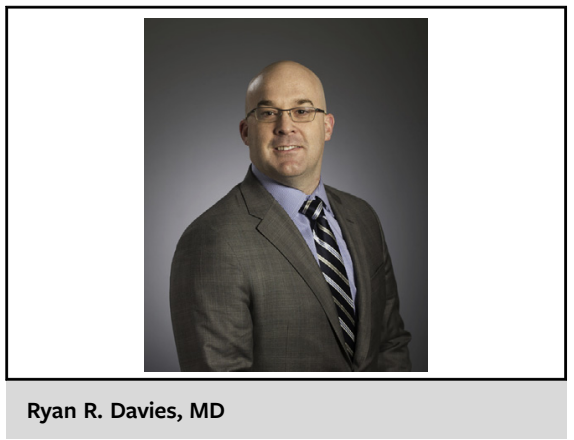

\author{
CENTRAL MESSAGE \\ Performance of a cone proced- \\ ure after a neonatal modified \\ Starnes may optimize long-term \\ outcomes by providing effective \\ early palliation with a long-term \\ biventricular circulation.
}

The technique described by the authors of subsequently performing a take-down of the right ventricular exclusion patch and performing a cone procedure suggests that these patients are not inevitably headed down a single-ventricle palliation pathway forever.

The flexibility of the approach by da Silva and colleagues is perhaps its greatest advantage. One of the primary challenges with Ebstein anomaly is the clinical heterogeneity and the challenge of selecting the appropriate procedure for the appropriate patient, thereby maximizing both shortand long-term survival. The option to restore a biventricular circulation after the cone procedure suggests that decisions made in the first weeks of life need not be irrevocable.

However, this technique may simply be pushing challenging decisions into later childhood. A case series of 2 patients cannot begin to answer all of the important questions: who should get this procedure? What preoperative assessments can inform whether a patient will tolerate it? Are there techniques for right ventricular exclusion that will optimize the function of the right ventricle and make sure a repair more likely? Which patients will benefit from conversion to a $1 \frac{1}{2} 2$-ventricle repair using a cone procedure and a superior cavopulmonary connection? These are important questions, and it will take time to accumulate experience.

Despite the unanswered questions, the technique holds promise. By enabling the conversion from the singleventricle palliation of a Starnes procedure to a long-term biventricular (or $1 \frac{1}{2}$ ventricle) circulation, we may be able to achieve the best of both worlds: effective and safe early 
treatment of the neonate in cardiogenic shock with eventual biventricular conversion and avoidance of long-term cavopulmonary palliation.

\section{References}

1. Starnes VA, Pitlick PT, Bernstein D, Griffin ML, Choy M, Shumway NE. Ebstein's anomaly appearing in the neonate. A new surgical approach. J Thorac Cardiovasc Surg. 1991;101:1082-7.

2. Kumar SR, Kung G, Noh N, Castillo N, Fagan B, Wells WJ, et al. Single-ventricle outcomes after neonatal palliation of severe Ebstein anomaly with modified starnes procedure. Circulation. 2016;134:1257-64.
3. da Silva JP, Viegas M, Castro-Medina M, da Silva LF. The da Silva cone operation after the Starnes procedure for Ebstein's anomaly: new surgical strategy and initial results. J Thorac Cardiovas Surg Tech. 2020;3:281-3.

4. Pizarro C, Bhat MA, Temple J. Cone reconstruction and ventricular septal defect closure for neonatal Ebstein's anomaly. Multimed Man Cardiothorac Surg. 2012; 2012:mms014.

5. Mizuno M, Hoashi T, Sakaguchi H, Kagisaki K, Kitano M, Kurosaki K, et al Application of cone reconstruction for neonatal Ebstein anomaly or tricuspid valve dysplasia. Ann Thorac Surg. 2016;101:1811-7.

6. Huang S-C, Wu E-T, Chen S-J, Huang C-H, Shih J-C, Chou H-W, et al. Surgical strategy toward biventricular repair for severe Ebstein anomaly in neonates and infancy. Ann Thorac Surg. 2017;104:917-25. 